\title{
Optimization of Water Pumping and Injection for Underground Coal Gasification in the Meiguiying Mine, China
}

\author{
Donglin Dong ${ }^{1} \cdot$ Mingdong Zhao ${ }^{1} \cdot$ Gang Lin $^{1,2} \cdot$ Weijun Zhao ${ }^{1} \cdot$ Kai Zhang $^{1} \cdot$ \\ Neng $\mathbf{L i}^{\mathbf{1}}$
}

Received: 26 May 2015 / Accepted: 1 February 2016/Published online: 9 February 2016

(C) Springer-Verlag Berlin Heidelberg 2016

\begin{abstract}
The Meiguiying mine is a famous underground coal gasification (UCG) mine in China, but there has been a potential safety hazard since it began operating, that groundwater in the overlying aquifer might enter the mine and even extinguish the gasifier. A 3-D hydrogeological model was developed to explore the characteristics of the seepage field of the aquifer and determine an optimal water pumping and injection option for the UCG. The results indicate that more attention should be paid to control induced fractures of the roof due to the increasing water level of the aquifer, and that a pumping rate of $160 \mathrm{~m}^{3} / \mathrm{day}$ would decrease the water level to a reasonable elevation. Moreover, to maintain the groundwater table and mine safety, $120 \mathrm{~m}^{3} /$ day was recommended as a reasonable and economical recharge (re-injection) rate in the study area.
\end{abstract}

Keywords Hydrogeological model · Seepage field · Optimization drainage options · Water injection

Electronic supplementary material The online version of this article (doi:10.1007/s10230-016-0389-1) contains supplementary material, which is available to authorized users.

Gang Lin

lingangqq@163.com

1 Department of Geological Engineering and Environment, China University of Mining and Technology, Beijing (CUMTB), Beijing 100083, China

2 Institute of Geographical Sciences and Natural Resources Research, Chinese Academy of Sciences, Beijing 100101, China

\section{Introduction}

Underground coal gasification (UCG) is a relatively new technology for using coal resources efficiently and cleanly (Khadse et al. 2007; Shafirovich and Varma 2009). In China, more than $65 \%$ of the energy consumed is from coal and $70 \%$ of their electric power (Trinnaman and Clarke 2004). Hence, there is a great need to develop UCG technology in China. Since 1991, China has made some strides in UCG research, and has implemented at least 16 tests (Burton et al. 2006; Li et al. 2012; Yang et al. 2013). Liu et al. (2011) also established a mathematic and numerical model to study the phenol migration for UCG. However, the previous studies do not systematically forecast and analyze the UCG seepage fields.

The Meiguiying Mine is located in the midwest of the Inner Mongolia Autonomous Region, in China (Fig. 1). The tectonics of the mine is simple; it has a shallowly dipping monoclinal structure with a few small folds in a single direction. There are three major faults in the area and the coal seams have not been influenced by magmatic rock. However, there is a major threat that groundwater in the overlying aquifer might enter the mine via a water-filled fractured zone and extinguish the gasifier. Therefore, an understanding of the seepage fields in the overlying aquifer and an accurate mine drainage capacity are essential to ensure safe and efficient production. This study was undertaken to determine the appropriate water level in the aquifer overlying the coal roof. A three dimensional (3-D) hydrogeological model was developed to explore the characteristics of the aquifer's seepage field and reduce the likelihood of water inrush. An optimal water pumping and re-injection plan was also developed. 
Fig. 1 Location map of the study area

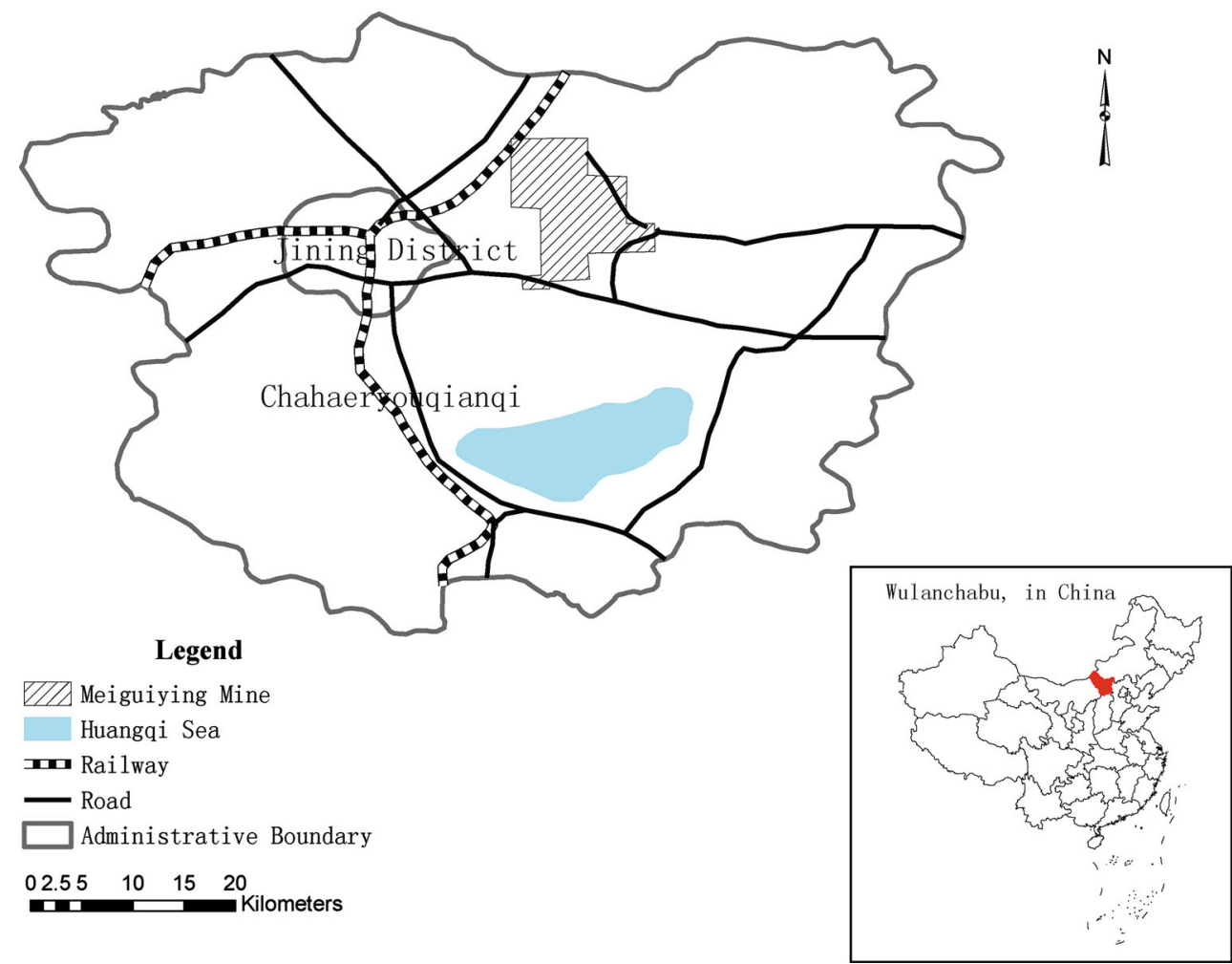

\section{Hydrogeology of the Meiguiying Mine}

The study area is mostly Cenozoic and Mesozoic sedimentary rocks, and the strata are, from bottom to top, a Paleogene sandstone and sandy mudstone formation, a Neogene basalt formation, and Quaternary alluvium; there are also Mesoarchean Erathem metamorphic rocks in the basement of the basin. The climatic characteristics in this area is semi-arid, with scarce precipitation; the groundwater recharge in this area mainly comes from infiltration of precipitation and pore-fissure water into the bedrock. The runoff direction of the groundwater is consistent with the terrain, which slopes from north to south.

The Huerjing Group of the Paleogene is the main coal measure strata. According to the exploration and survey data, the Neogene basalt contains many cavity fractures, and is the main aquifer overlying the coal roof in that it has a high water yield. The mudstone that lies between the basalt and the coal seam is the main aquiclude.

\section{Methodology}

\section{Numerical Simulation Using MODFLOW-2000}

Hydrogeological data of the Meiguiying mine were available in Autocad and Longruan GIS format. We converted the datasets to shape-files using ArcGIS9.3 for the boundary conditions and the hydrogeological characteristics to establish a MODFLOW-2000 (Harbaugh et al. 2000) model for this study. MODFLOW (McDonald and Harbaugh 1988) is a 3-D finite-difference groundwater model for a porous medium designed by the U.S. Geological Survey (USGS). MODFLOW-2000 was designed to accommodate the solution of other equations in addition to the groundwater flow equation (Harbaugh et al. 2000).

\section{Discretization and Generalization of Boundaries and Seepage Flow}

Regional groundwater flow varies with space and time (unsteady), reflecting spatial heterogeneity. Thus, a transient model was required. Based on an analysis of the conceptual model and the existing datasets, the model was automatic divided into 10,000 grids $(100 \times 100)$. Based on the seepage flow characteristics of the aquifer and the stratigraphic structure, the boundaries were grouped into different specified flux boundaries. The north boundary is regarded as the recharge boundary and the southern border is considered to be the discharge boundary. The eastern and western boundaries were assigned to be impermeable. The groundwater flows generally from north to south; the northern initial water level was $1337 \mathrm{~m}$ and the southern was $1334 \mathrm{~m}$. 


\section{Treatment of the Simulation Period}

The flow field in January 2007 was designated as the initial flow field for the groundwater resource; the flow field in January 2009 was designated as the fitting flow field, with those 2 years serving as the simulation period, which was divided into 90 day stress periods. Each stress period contains several time steps, which was automatically controlled by the model.

\section{Calibration of the Model and Evolution of the Aquifer Seepage Field}

The observed data of observation wells (g1, g4) were used to calibrate the model. Figure 2 shows the fitting chart of observation well g1 (a) and g4 (b). The calculated and observed values agreed well, indicating favorable predictive ability.

\section{Results and Discussion}

Figure $3 \mathrm{a}, \mathrm{b}$ showed the simulated water levels in two different scenarios: before (a) and after ignition (b). Initially, the simulated water level at the cone center was $1281 \mathrm{~m}$; however, the simulated water level at the cone center was changed to $1294 \mathrm{~m}$ because ignition generally increases groundwater pressure in the roof strata. This greater water pressure would push the water in the aquifer into induced fractures, and thus into the mine. Therefore, long-term and dynamic observation of water levels in this aquifer is necessary.
Fig. 2 The fitting chart of observation wells g1 (a) and g4 (b)
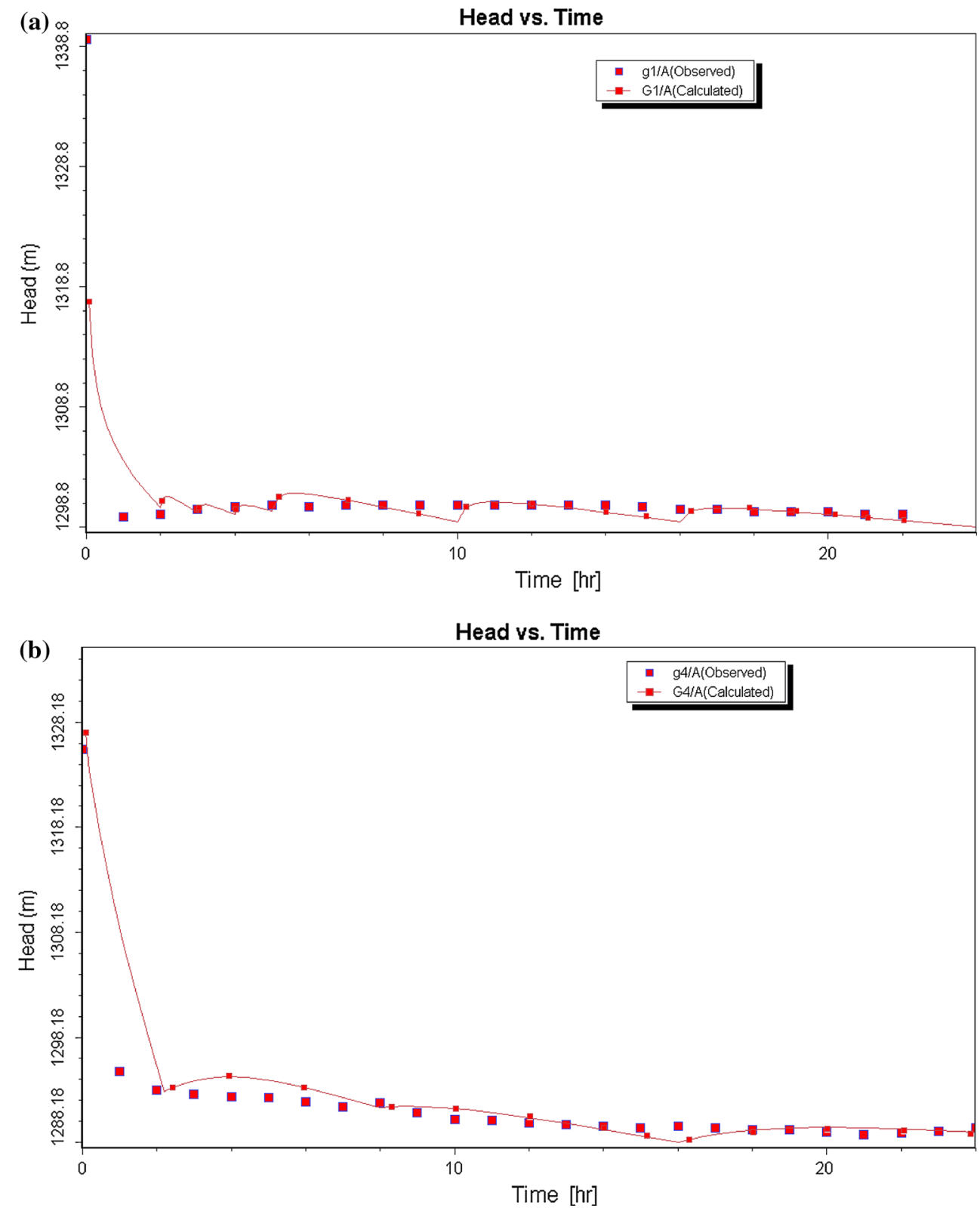
Fig. 3 The simulated water levels of the roof aquifer in different scenarios: a before and b after ignition
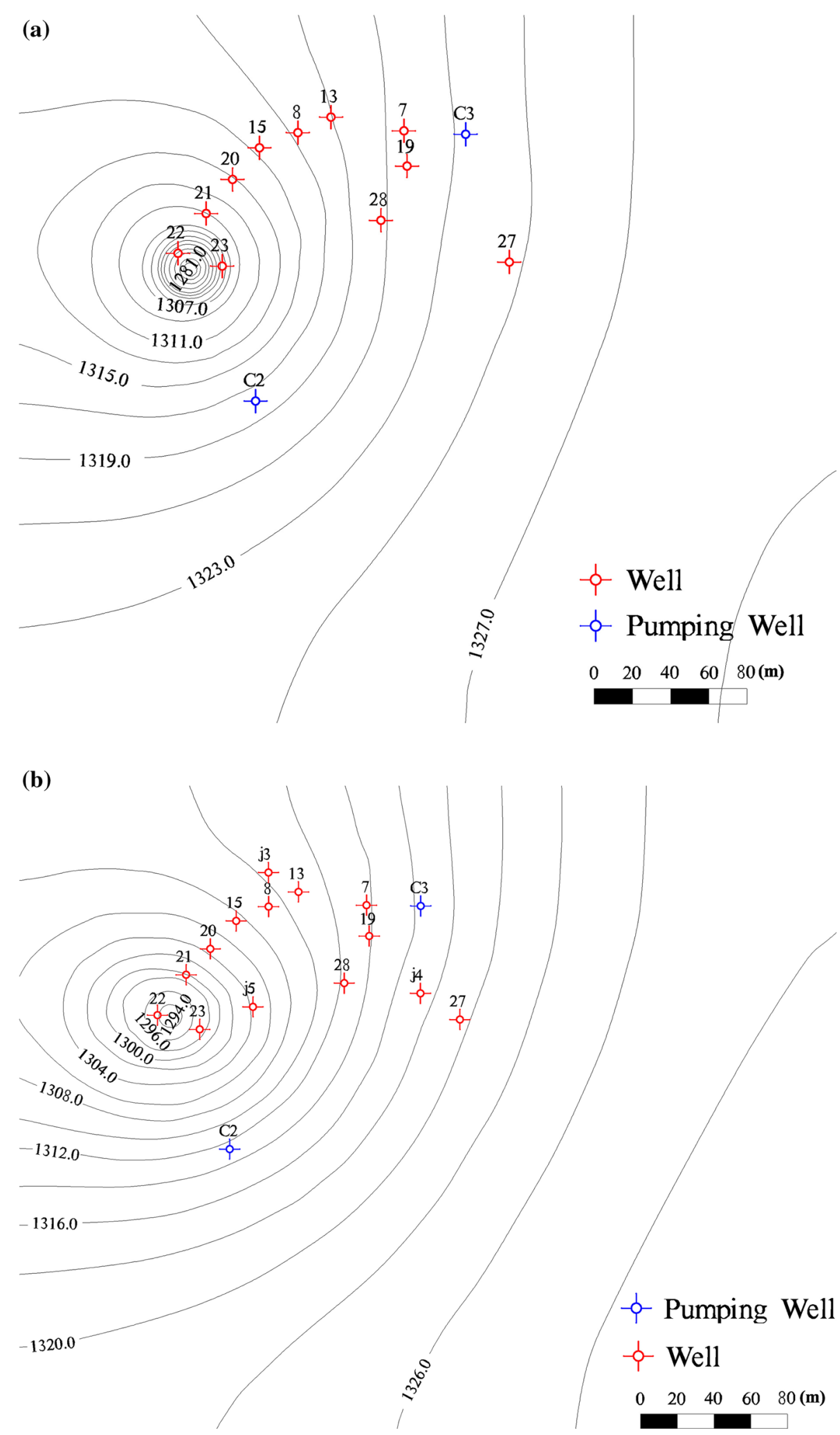

To decrease the water level, we incorporated two dewatering wells $(\mathrm{C} 2, \mathrm{C} 3)$, one on both sides of the gasification zone, and simulated the water level at different pumping rates. Of course, groundwater recharge had to be considered to maintain a groundwater balance. For that, we incorporated a well (Z1) that re-injected the pumped water at a down-gradient distance exceeding $150 \mathrm{~m}$ from $\mathrm{C} 2$, and explored the characteristics of the seepage field of the burn zone. The 
Fig. 4 Effects of an $80 \mathrm{~m}^{3} /$ day extraction rate, without (a), and with (b) a recharge well with an injection rate of $120 \mathrm{~m}^{3} /$ day

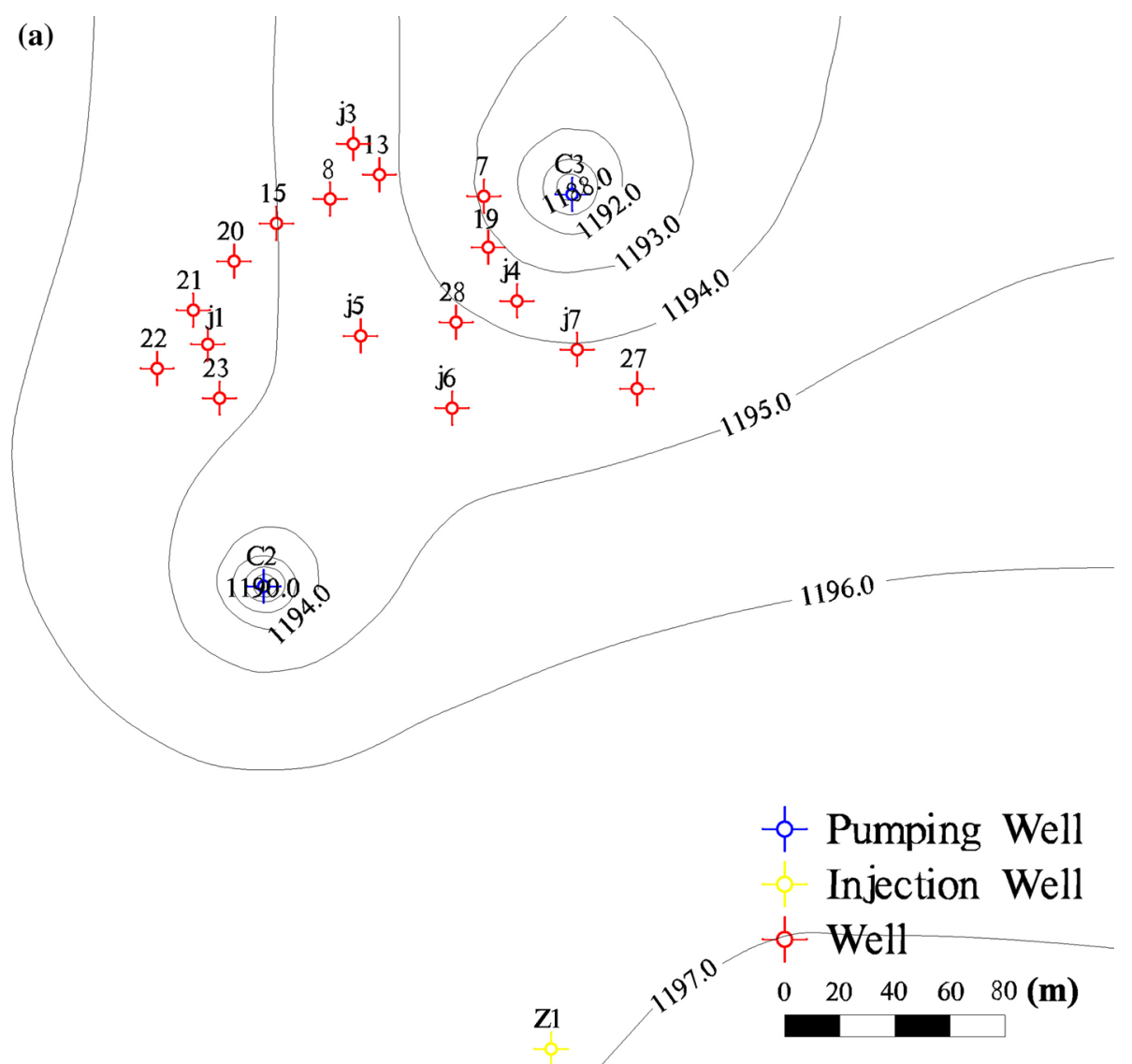

(b)

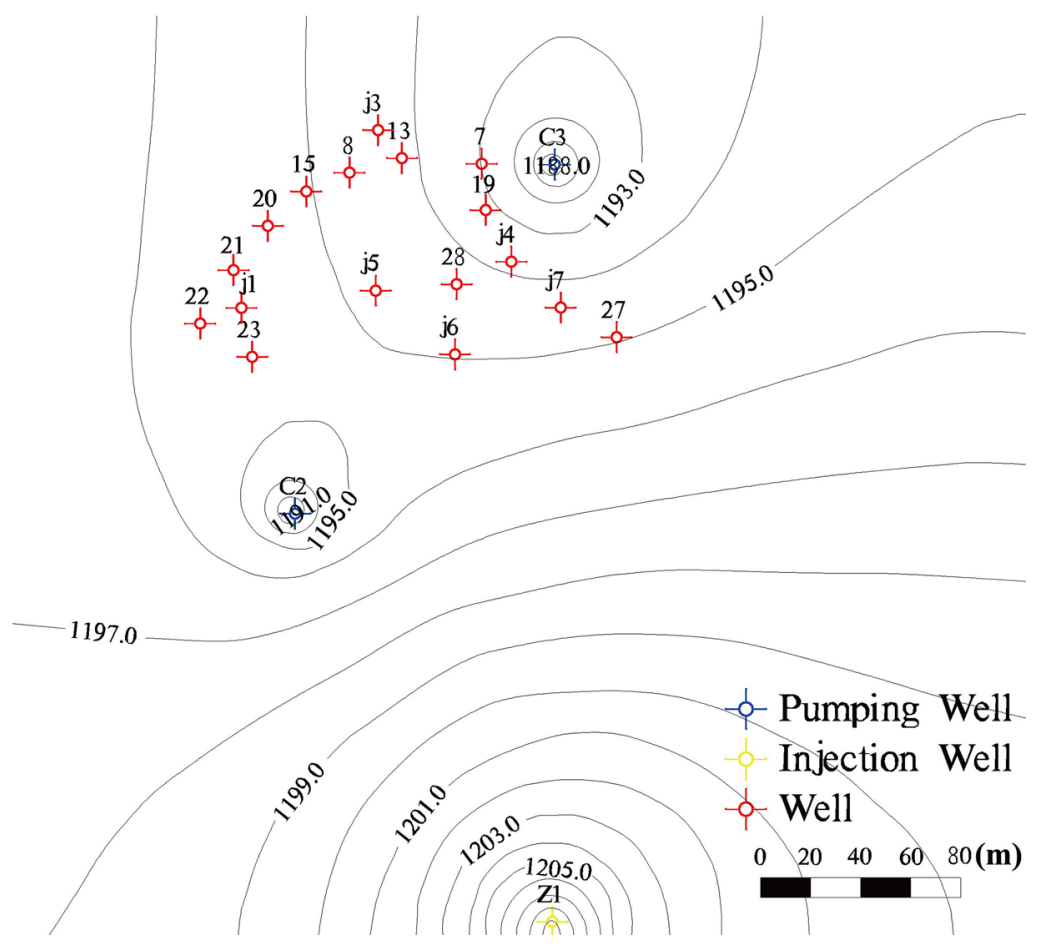


injection water volume was determined based on the amount of groundwater being extracted, excluding the production water (cooling systems, gasification reaction, etc.); thus considering the production practice, $120 \mathrm{~m}^{3} /$ day was determined as a reasonable and economical recharge (re-injection) rate. Scenarios (1)-(5) show how each dewatering well was assigned a pumping rate of $80,120,160,210$, or $258 \mathrm{~m}^{3} /$ day, respectively, and how the characteristics of the seepage field combined with the recharge well was addressed:

(1) Scenarios in which the extraction rate was set at $80 \mathrm{~m}^{3} /$ day without (Fig. 4a), and with (Fig. 4b) recharge wells with an injection rate of $120 \mathrm{~m}^{3} /$ day. Without a recharge well, the water level of the cone center of well C2 was $1190 \mathrm{~m}$, and the water level of the cone center of well C3 was $1188 \mathrm{~m}$; incorporating the recharge well, the water level of the cone center of well C2 changed to $1191 \mathrm{~m}$, and the water level of the cone center of well C3 changed to $1188 \mathrm{~m}$.

(2) Scenarios in which the extraction rate was set at $120 \mathrm{~m}^{3} /$ day without [Supplemental Figure 1 (a)], and with [Supplemental Figure 1 (b)] recharge wells with an injection rate of $120 \mathrm{~m}^{3} /$ day. Without the recharge well, the water level of the cone center of well C2 was $1185 \mathrm{~m}$, and the water level of the cone center of well C3 was $1183 \mathrm{~m}$; when considering a recharge well, the water level of the cone center of well $\mathrm{C} 2$ changed to $1188 \mathrm{~m}$, and the water level of the cone center of well C3 changed to $1184 \mathrm{~m}$.

(3) Scenarios in which the extraction rate was set at $160 \mathrm{~m}^{3} /$ day without [Supplemental Figure 2 (a)], and with [Supplemental Figure 2 (a)] recharge wells with an injection rate of $120 \mathrm{~m}^{3} /$ day. Without the recharge well, the water level of the cone center of well C2 was $1179 \mathrm{~m}$, and the water level of the cone center of well C3 was $1176 \mathrm{~m}$; when considering the recharge well, the water level of the cone center of well C2 changed to $1183 \mathrm{~m}$, and the water level of the cone center of well C3 changed to $1177 \mathrm{~m}$.

(4) Scenarios in which the extraction rate was set at $210 \mathrm{~m}^{3} /$ day without [Supplemental Figure 3 (a)], and with [Supplemental Figure 3 (a)] recharge wells with an injection rate of $120 \mathrm{~m}^{3} /$ day. Without the recharge well, the water level of the cone center of well C2 was $1174 \mathrm{~m}$, and the water level of the cone center of well C3 was $1171 \mathrm{~m}$; when considering the recharge well, the water level of the cone center of well C2 changed to $1180 \mathrm{~m}$, and the water level of the cone center of well C3 changed to $1172 \mathrm{~m}$.

(5) Scenarios in which the extraction rate was set at $258 \mathrm{~m}^{3} /$ day without [Supplemental Figure 4 (a)], and with [Supplemental Figure 4 (a)] recharge wells with an injection rate of $120 \mathrm{~m}^{3} /$ day. Without the recharge well, the water level of the cone center of well $\mathrm{C} 2$ was $1172 \mathrm{~m}$, and the water level of the cone center of well C3 was $1160 \mathrm{~m}$; when considering the recharge well, the water level of the cone center of well $\mathrm{C} 2$ changed to $1175 \mathrm{~m}$, and the water level of the cone center of well C3 changed to $1164 \mathrm{~m}$.

Figure 4 and Supplemental Figure 1-4 show that the water level of the gasification zone was reduced by an increased pumping rate and was lowest when the extraction rate was $258 \mathrm{~m}^{3} / \mathrm{day}$. When the extraction rate was increased from 120 to $160 \mathrm{~m}^{3} /$ day, the water level decrease was obvious, while increasing the pumping rate beyond $160 \mathrm{~m}^{3} /$ day produced a more subtle decrease. Since a water level of $1175 \mathrm{~m}$ satisfied the safety envelope for UCG, $160 \mathrm{~m}^{3} /$ day was considered an optimal pumping rate for the operation ( $\mathrm{Xu}$ 2014). Incorporation of a recharge well affected the seepage field a little in each scenario, but there was no substantial increase of the water level around the gasification zone, especially near $\mathrm{C} 3$, which was the main burn zone. Therefore, it was deemed scientifically sound and economically prudent to incorporate a recharge well (Z1) with a rate of $120 \mathrm{~m}^{3} /$ day to maintain the groundwater table.

The parameters (hydraulic conductivity or permeability, specific storage coefficient, etc.) used in our model didn't consider the influence of temperature, which might have affected the seepage field characteristics. Differences exist between longwall mining and UCG, due, for instance, to the lithological effects of incomplete burning and the ignition temperature. Previous studies have reported that water pressure can be affected by temperature (Pan and Zhang 2006), and that other parameters, such as hydraulic conductivity or permeability and storage coefficient, are greatly dependent on temperature and pressure (Huang and Rudnicki 2006; Yang and Zhou 1995). Younger (2011) also found that the high buoyancy of the syngas relative to groundwater can heat groundwater around the burn zone. Thus, high temperatures and increased pore-water pressure do affect the parameters used in our model; however, the lack of accurate temperature datasets around the burn zone makes it difficult to develop a model that can be used to explore the characteristics of the UCG seepage field. More studies that focus on how temperature influences seepage are needed.

\section{Conclusions}

This study explored the characteristics of the aquifer overlying the burn zone for UCG in the Meiguiying Mine and discussed optimization of mine drainage capacity and water re-injection for a safe operation. The following main conclusions were reached: 
(1) In the UCG process, the water level of the aquifer overlying the burn zone could be increased by ignition, and the groundwater in the aquifer overlying the coal roof may flow via the induced fractures into the coal seams, which could extinguish the gasifier. Long-term monitoring of the water level and control of induced roof fractures are necessary.

(2) Considering both mine safety and economics, the optimal water extraction rate should be about $160 \mathrm{~m}^{3} /$ day, and a reasonable water level in the aquifer above the main burn zone should be about $1175 \mathrm{~m}$.

(3) The seepage field of the aquifer overlying the burn zoon was analyzed under two scenarios: with and without a recharge well. The seepage field of the burn zone was only affected slightly when a recharge well rate of $120 \mathrm{~m}^{3} /$ day was assigned.

In this paper, the seepage field of the overlying aquifer of the gasification was discussed using numerical simulation; however, the issue is complicated and needs more attention.

Acknowledgments This study was financially supported by the Fundamental Research Funds for the Central Universities (2009QD03), Natural Science Foundation of Beijing Municipality (8122037) and National Natural Science Foundation of China (41172213 and 41272275), which we gratefully acknowledge.

\section{References}

Burton E, Friedmann J, Upadhye R (2006) Best practices in underground coal gasification. Lawrence Livermore National
Laboratory. http://www.purdue.edu/discoverypark/energy/assets/ pdfs/cctr/BestPracticesinUCG-draft.pdf

Harbaugh AW, Banta ER, Hill MC, McDonald MG (2000) MODFLOW-2000, the US Geological Survey modular ground-water model: user guide to modularization concepts and the groundwater flow process. US Geological Survey, Reston

Huang T, Rudnicki JW (2006) A mathematical model for seepage of deeply buried groundwater under higher pressure and temperature. J Hydrol 327:42-54

Khadse A, Qayyumi M, Mahajani S, Aghalayam P (2007) Underground coal gasification: a new clean coal utilization technique for India. Energy 32:2061-2071

Li J, Wang Y, Gao B, Liu H, Yao K, Zhang S (2012) Experiment study on pollutants generation feature model of underground coal gasification. Coal Sci Technol 40:112-116 (in Chinese)

Liu S, Dong G, Yang G, Li J, Gao B, Liang J, Chen F (2011) Numerical simulation of phenol migration for underground coal gasification. J China Coal Soc 36:796-801 (in Chinese)

McDonald MG, Harbaugh AW (1988) A modular three-dimensional finite-difference ground-water flow model. U.S. Geological Survey, Reston, VA, USA. http://pubs.er.usgs.gov/publication/ twri06A1

Pan Y, Zhang H (2006) Effect of temperature variation on hydraulic pressure test of steel pipelines. Pet Eng Constr 32:10-13 (in Chinese)

Shafirovich E, Varma A (2009) Underground coal gasification: a brief review of current status. Ind Eng Chem Res 48:7865-7875

Trinnaman J, Clarke A (2004) Survey of energy resources. World Energy Council, Elsevier, London

$\mathrm{Xu} \mathrm{Y} \mathrm{(2014)} \mathrm{Underground} \mathrm{coal} \mathrm{gasification} \mathrm{process} \mathrm{characteristic} \mathrm{of}$ roof rock permeability. MS thesis, Taiyuan Univ of Technology (in Chinese)

Yang L, Zhou X (1995) Research of deep groundwater seepage field. Chengdu University of Science and Technology Press, Chengdu (in Chinese)

Yang L, Pan X, Dong G (2013) Study on model test of underground gasification of coking coal. Coal Sci Tech 41:16-18 (in Chinese)

Younger PL (2011) Hydrogeological and geomechanical aspects of underground coal gasification and its direct coupling to carbon capture and storage. Mine Water Environ 30:127-140 